\title{
Palynomorphs of the First Down-Hole Shale Occurrence in Three Contiguous Basins in Nigeria: Implication on the K-Pg Boundary
}

\author{
Peter S. Ola ${ }^{1}$ and Blessing Adeoti ${ }^{2}$ \\ Department of Applied Geology, Federal University of Technology, P.M.B. 704 Akure, Nigeria \\ Email: ${ }^{1}$ psolang@yahoo.com, ${ }^{2}$ badeoti@futa.edu.ng
}

\begin{abstract}
Attempt was made to retrieve palynomorph and calcareous nannofossil from samples retrieved from first down-hole shale occurrence in three contiguous basins (Anambra, Bida and Benin Basins) in Nigeria with a view to determining their ages, paleoecology and the K-Pg boundary. A total of one hundred and sixteen species were recovered from all the samples. The occurrence of Echitriporites trianguliformis in the Anambra basin suggests ages of Campanian to Maastrichtian, while the common occurrence of Retitricolporites sp which is Paleocene to Eocene in samples from Anambra and Bida Basins confirms age relation. This modern palm (Retitricolporites sp) and fungal spores as well as the absence of algae spores and nannofossil suggest swamp environment of deposition and a hot tropical to subtropical climate. Its absence in the Benin basin suggests a little deviation in the age of deposition. An observed spike in the occurrence of Cyathidites sp and Laevigatosporites sp in the Okeluse samples suggest K-Pg boundary.
\end{abstract}

Keywords: K-Pg boundary, Nigeria, palynormorphys, Cyathidites sp, Laevigatosporites sp.

\section{Highlight:}

The first down-hole shales in three contiguous basins were studied for K-Pg boundary

The shales contain long-ranging forms like Echitriporites trianguliformis

Cyathidites sp and Laevigatosporites sp spikes suggest K-Pg boundary

Absence of nannofossil and fungal spore suggests swamp environment of deposition

Further study using Iridium anomaly recommended

\section{Introduction}

The relict of the K-Pg boundary resulting from the asteroid impact on the biosphere that occurred about $66 \mathrm{Ma}$ ago has been recorded worldwide. The impact led to abrupt global ecosystems disruptions and a global extinction of several fossil groups. Major losses with widespread changes in terrestrial and marine biotic representation were also recorded within groups that did not go extinct. According to Vadja and Bercovici (2014), about $350 \mathrm{k}$-pg boundary sections have been described globally, among which 105 are terrestrial deposits. Prominent among the evidence of this event is occurrence of iridium anomaly, which has been used extensively to define the boundary (Slimani et al,. 2010). Notwithstanding, records show that the K-Pg boundary is not marked by a mass extinction of dinoflagellate cyst species, but shows important changes in relative abundances of different species or group of morphologically related species in a section in northern Mexico (Slimani et al., 2010). The dynamics of the plant cover is another major component of the biological response across the $\mathrm{K}-\mathrm{Pg}$ interval and associated destabilization worldwide suggesting the usefulness of palynology in the identification of the boundary.

In Nigeria, the K-Pg boundary appears yet to be identified at outcrops, in spite of the numerous outcrops already described in the literature. The area around the central portion of Nigeria at the interception of the Bida Basin, Anambra Basin and the Dahomey Basin constitute the best target area to get this boundary at outcrop. This is because by the beginning of the Paleogene evidence abound that the focus of sedimentation in most of the cratonic basins in Nigeria shifted southward from the central 
area and northward i.e. to the Bornu sub-Basins of the mega- Chad Basin. Generally, the formation of the cratonic basins in Nigeria followed the break-up of the South American and African continents in the Early Cretaceous (Murat, 1972; Burke, 1996) but various lines of evidence abound to support the evolution of the Bida and Anambra Basins during the Anambra-Benin phase (Campanian-Mid Eocene) of the three phases of the development of the southern Nigerian sedimentary basins. On the Geological Survey Map of Nigeria, the area is expressed as being covered by the Nkporo shale (Fig.1A).

The primary focus of this study is to examine palynological evidence for the establishment of the K$\mathrm{Pg}$ boundary in the area around the interception of these three contiguous basins: the Bida Basin, the Anambra Basin and the southwestern Nigerian portion of the Dahomey Basin in Nigeria. The study also examines the possible biostratigraphic relationship among the three contiguous basins in terms of a merger during the transition between the Cretaceous and Paleogene. The study is based on outcrop and very shallow borehole drilled for ground water exploitation.

\section{Geological Background}

\subsection{Basin Evolution}

The evolution of sedimentary basins in the West Central Africa Rift Systems (Genick, 1993), which includes the hydrocarbon rich, Gulf of Guinea Province and that of the West-Central Coastal Province (Brownfield and Charpentier (2006) has been described in a framework classified into pre-rift, syn-rift and post rift. The pre-rift incorporates Pan-African orogenic events, which in addition to creating cratons likely generated major lineaments or incipient faulted areas along which rifting occurred during the syn-rift phases in the Cretaceous. The most prominent rifting event is the separation of the African and the South American plates. Other events include formation of sedimentary basins along the presage fault zones. Post-rift events include the closing of the formed basins and some volcanic activities. In addition, the post rift events led to significant change in the focus of sedimentation along the faulted zones.

In Nigeria, while no evidence of the pre-rift sedimentation has been shown, Syn-rift sedimentation in the Abakali-Benue axis including Bornu sub-basin of the Mega-Chad Basin and Dahomey Embayment (Aptian -Santonian) are well documented. Following the collision of the African and the Eurasian Plates in the Santonian, and movement reversal of the African plate, all the already formed basins were subjected to compression that resulted in folding and faulting. Folding in the Abakaliki-Benue trough axis caused a change in sedimentation axis southward leading to the formation of the Anambra Basin. The Anambra Basin is a synclinal structure consisting of more than 5,000m thick of Upper Cretaceous to Recent sediments representing the third phase of marine sedimentation in the Benue Trough (Ladipo, 1988; Akande and Erdtmann, 1998). The Bida Basin is often taken to be a northwesterly extension of the Anambra Basin or an extension (N/W-S/E) of the Benue rift. It has been described as a rifted, sag Basin or a gently down-warped trough (Brownfield and Charpentier, 2006). Importantly, the geology indicates a rift related origin (King 1950; Kogbe et al., 1981; Ojo and Ajakaiye, 1989), which associates with the Benue Trough system. The basin consists of Upper Cretaceous clastic sequence of sandstones, shales, siltstones and ironstones.

The Nigerian portion of the Dahomey Basin extends from the boundary between Nigeria and Republic of Benin to the Benin Hinge Line down to the Atlantic Ocean (offshore). At the onshore area of the basin, both the Cretaceous and Tertiary rocks outcrop.

\section{$2.2 \quad$ Stratigraphic Consideration}

Based on Figure 2, the stratigraphic units where the K-Pg boundary could be found in the study area consist of Araromi Shale/Imo Formatios in the Benin Basin, Imo and Nsukka/Ajali/Mamu/ Enugu/ Nkporo in the Anambra Basin and the Agbaja/Patti/Lokoja/Batati/Enagi/Sakpa and Bida Formations in the Bida Basin. All these formations have been studied at outcrop. An outcropped section of Enugu shale at Agbogugu, Anambra Basin contains Ammobacultiesamabensis, Haphragmoides saheliense, Siroplectammina hausorum textularia gilbedina, Ammobaculities sp and Haplophragmoldes sp (Omoboriowo et at., 2012). These are benthos that span from Campanian to Maastrichtian, deposited in 
a coastal swamp, tidal flat to estuarine, delta front to inner neritic environments of deposition (Omoboriowo, et al., 2012).

The Mamu Formation that is characterized by fossiliferous dark gray, indurated, fissile shale, overlain by intercalation of sand and shale facies sequence with coal inter-beds inferring deposition under shallow marine conditions has been dated Middle-Upper Maastrichtian in the Anambra Basin (Ogala et al, 2009).

Within the Bida Basin the oldest facies have been dated Campanian (Adeleye, 1989). Outcrops of the Patti Formation within the basin occur in Ahoko. This formation consists of sandstones, siltstones, claystones and shales interbedded with bioturbated ironstones. Argillaceous units are said to predominate in the central parts of the basin. The siltstones of the Patti Formation are commonly parallel stratified with occasional soft sedimentary structures (e.g. slumps), and other structures such as wave ripples, convolute laminations, load structures (Obaje, 2009). The age of the Bida Formation is uncertain and has been speculated to be Campanian - Maastrichtian (Nwajide, 2013). Specifically, in the south eastern part of the Bida Basin where the microfloral assemblages of the Patti Formation had been studied, a Maastrichtian age was assigned to the formation.

Mebradu (1983) studied two outcropped sections at Ugbogui and Ofumwegbe along Benin-Lagos expressway in the western flank of the Anambra Basin (Fig.1B) and found that the sediment could be the regressive upper Cretaceous sediments (Campanian-Paleocene) or lateral equivalent of lower Imo formation of Paleocene age. This calls for a further review of his result.

\section{Methodology}

\subsection{Sample Location}

Samples were obtained from ten locations for this study. In the Anambra Basin samples were taken from Arimogija (N06 $49^{1} 42.0^{11}$, E005 $42^{1} 49.7^{11}$ ), Omolege junction (N06 $48^{1} 55.7^{11}$, E005 $38^{1} 33.1^{11}$ ) along Okeluse road, Ute $\left(\mathrm{N} 06^{\circ} 50^{1} 49.2^{11}\right.$, E005 $\left.36^{1} 42.3^{11}\right)$ and at Odiase camp (N06 $57^{1} 53.1^{11}$, E005 $44^{1} 38.1^{11}$ ) (Fig.1C). At Ute two samples were taken from shallow water borehole at two depths interval 140 and $200 \mathrm{ft}$. Three samples were collected from Ahoko area (E006 $51.474^{1}$ and N08 $\left.18.831^{1}\right)$ along road cut at about $7 \mathrm{~km}$ away from Gerinya junction, at Ahoko-Ebira along Lokoja Abuja express way in Bida basin (Fig. 1D).

\subsection{Palynomorphs}

Each of the samples was subjected to palynormorphs and calcareous nannofossils analysis. Fifteen grams of each of the samples were treated with $45 \%$ Hydrofluoric acid (HF) in a fume cupboard to remove silicate materials from the sample. Distilled water was used for rinsing. Hydrochloric acid $(\mathrm{HCl})$ was added to each of the samples and heated on hot plate for about 25- 30 minutes. Distilled water was added and left for one hour before decantation to eliminate the acid content. Brason Sonifier was used for sieving before the samples were centrifuged for about 3-5 minutes in order to separate the heavy material from the floating palynomorphs and lighter palynodebris.

The floating palynomorphs and lighter palynodebris were pipetted from the test tubes and uniformly spread over cover slips and allowed to dry for about one hour. Two drops of Canada balsam was used to glue the slide with the cover slip. The cover slips containing the dried residue were gently mounted over the glass slides. The slides were then allowed to dry under the sunlight for about 5-10 minutes.

The identification was done by using a light transmitted binocular microscope. Each prepared slide was scanned in turn on the movable stage microscope from end to end horizontally until the entire area of the cover slip was covered. Species name and the number of times each species encountered was counted and recorded on the palynology analysis sheet. Photomicrographs of the observable forms were taken. 

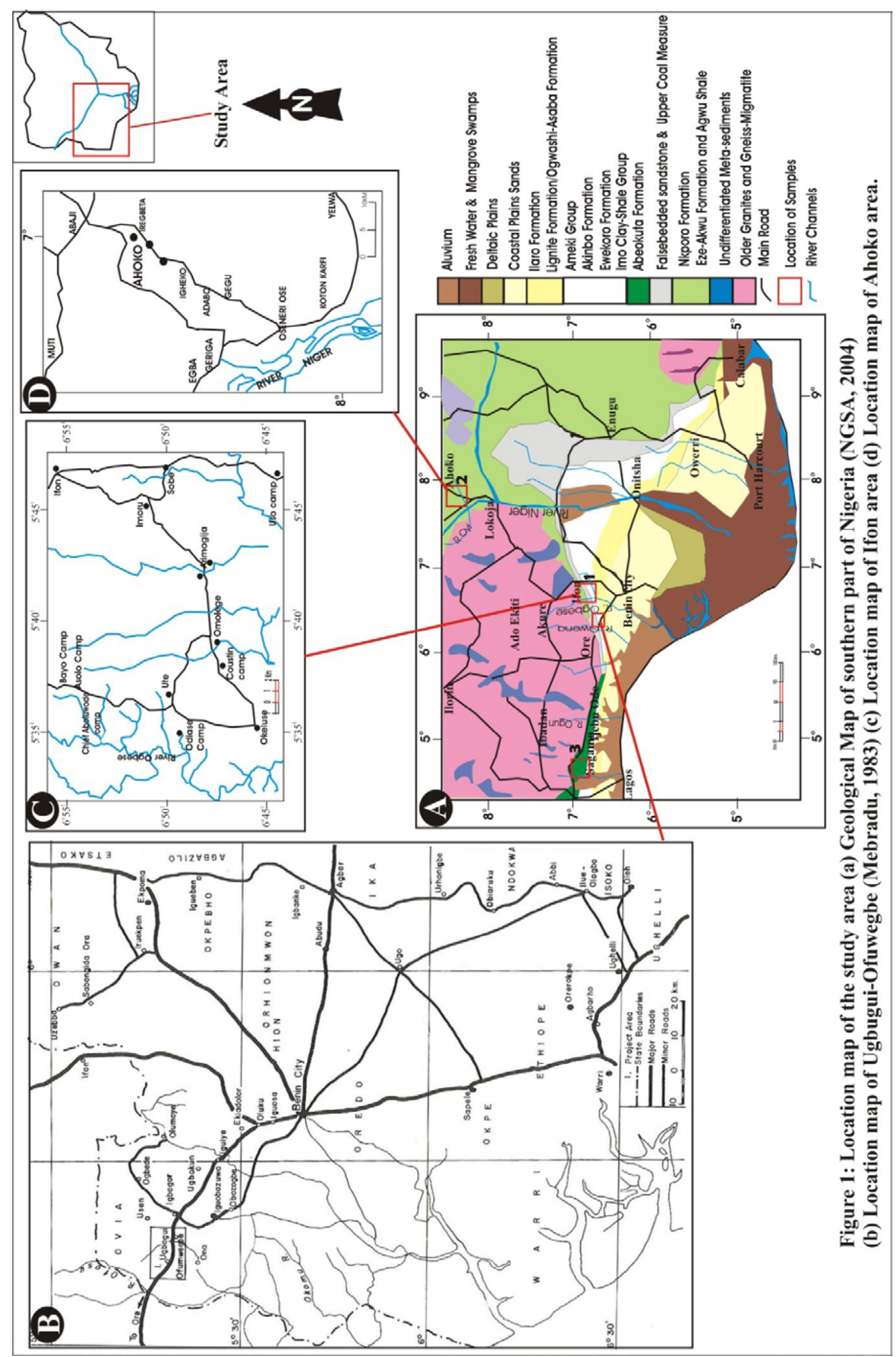


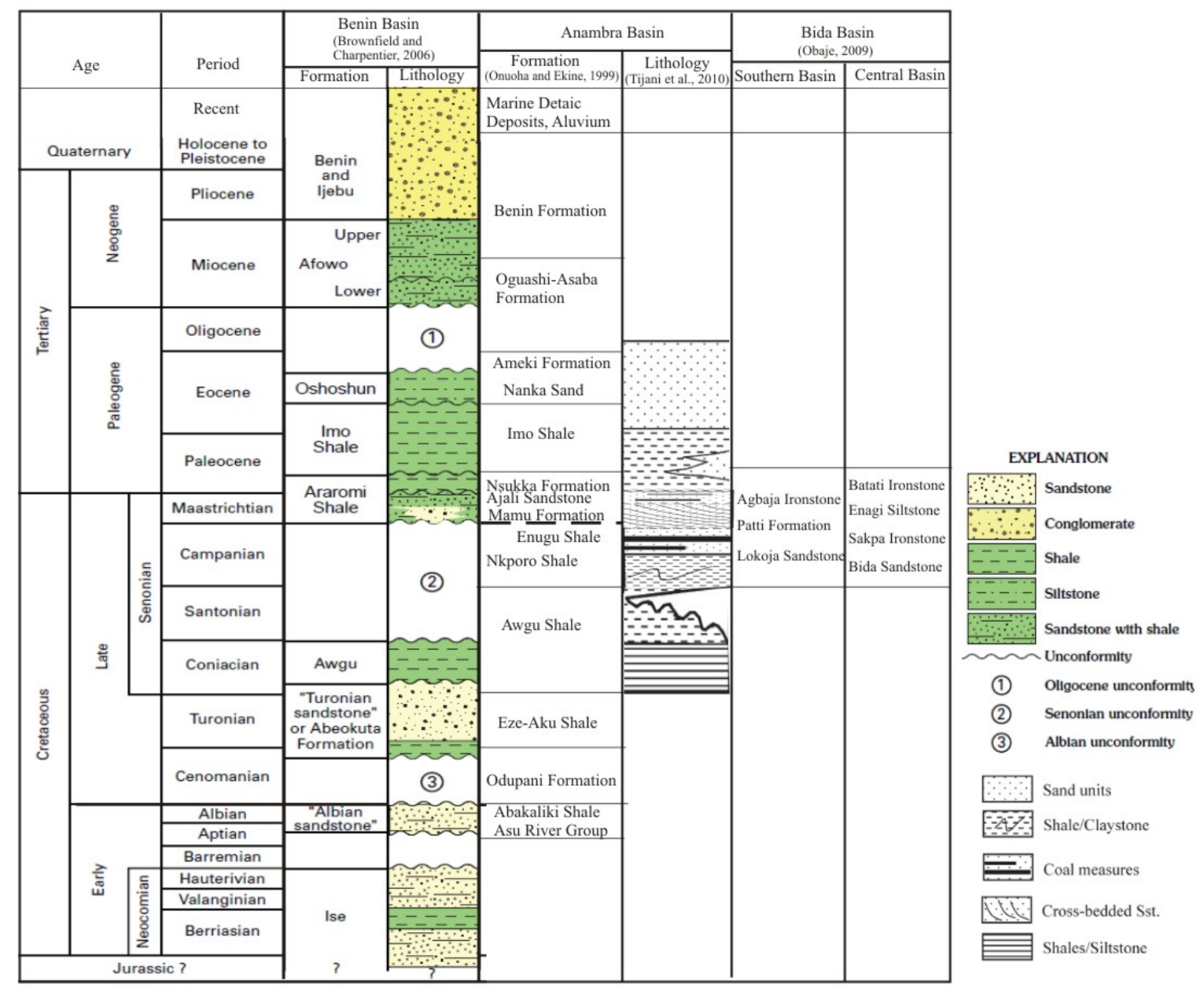

Figure 2. Stratigraphy of the Benin (Offshore and Onshore), Anambra and Bida basins.

\subsection{Calcareous Nannofossils}

Five grams of each sample was pulverized using mortar and pestle gently to avoid destroying the nannofossils in the sediment. The pulverized samples were then collected into the beaker and stirred in distilled water and then allowed to settle. The floating portion was gently collected with the disposable pipettes and spread on slides on the hot plate. The fluid on the slides was allowed to dry while still on the hot plate and finally covered using Canada balsam with the cover slips.

\section{Presentation and Interpretation of Data}

The palynological distribution chart is presented in Figure 3. The palynomorph recovery was moderate to poor. Only sediments collected from the Anambra and few from Bida Basins contain palynomorphs. In all, one hundred and sixteen forms made up of 65 species were recovered. No nannofossil was recovered from all the samples. The Anambra basin whose sediments are represented by L1 to L5 actually shows significant abundance of palynomorphs. Only location B2 among the samples collected in Ahoko section of the Bida Basin contains relatively few palynomorphs, while the other two samples (B1and B3) are completely barren. Similarly, the Benin Basin samples (C1 and C2) exhibit very poor palynomorphs recovery and were deemed barren. Of the recovered forms (Fig. 3), only Retitricolporites 
sp, Tricolporites sp are common to both the Anambra and Bida Basins while Laevigatosporites sp is common to all the three basins.
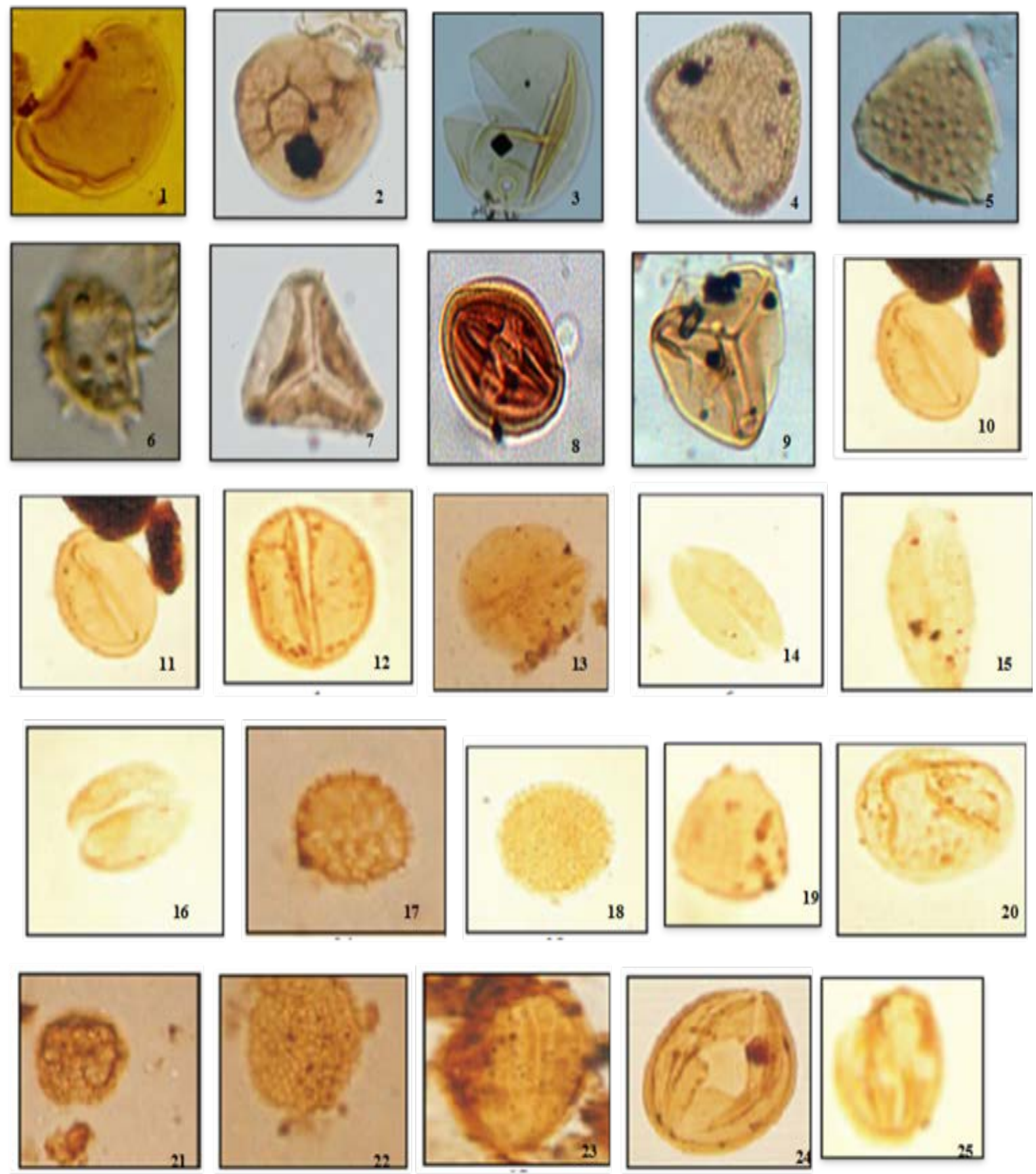

Figure 3. Palynological distribution chart of palynomorphs recovered from first down-hole shale from basins in the central portion of Nigeria. 


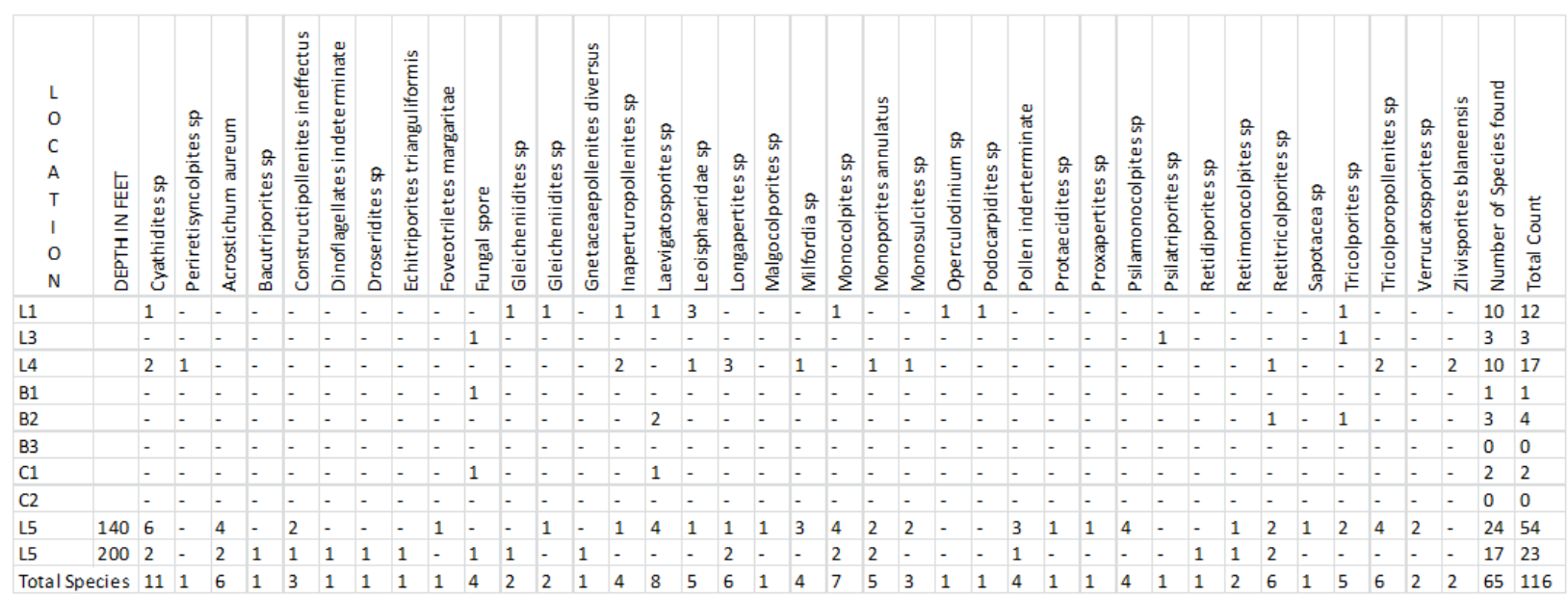

Plate 1. All figures x 400

1. Laevigatosporites sp

2. Zlivisporites blanensis

3. Monoporites annulatus

4. Foveotriletes magaritae

5. Echitriporites trianguliformis

6. Droseridities sp

7. Glechenidites senonicus

8. Leiosphaeridia sp

9. Cyathidites sp

10-13. Monocolpites marginatus (Ogala et al, 2009)
14-16. Monosulcites sp (Lawal and Moullade, 1986)

15-18. Constructipollenites ineffectus (Ogala et al 2009)

19. Echitriporites trianguliformis (Ogala et al, 2009)

20. Inaperturopollenites sp (Lawal and Moullade, 1986)

21-22. Zlivisporites blanensis (Ogala et al, 2009)

23. Retimonocolpites sp. (Lawal and Moullade, 1986)

24-25. Tricolporopollenites sp (Jardine and Magloire, 1965

\section{Discussion}

\subsection{Age Assignment}

Prominent among the recovered species is Echitriporites trianguliformis Van hoeken-Klinkenberg, 1964, which Mebradu et al., 1986 also recovered from the same section. Atta-Petters and Salami (2004) described two morphotypes (the finely and the coarsely echinate forms) of this species. The recovered one in this study appears like the coarsely echinate forms Plate 1. 19. According to Germeraad et al (1968), Echitriporites trianguliformis is a marker species that is common in the Upper Cretaceous of northern South America and though also important in the Eocene of Nigeria meaning that it ranges from Maastrichtian to Eocene age. Gleicheniiditessp, Zlivisporitesblaneensis, and Leoisphaeridae sp. form a good assemblage for Maastrichtian sediments. Another Maastricthian-Eocene form recovered in this study is Foveotriletes margaritae (Van der Hammen) Germeraad et al., 1968 and Atta-Petters and Salami, 2004). The LAD of Foveotriletes margaritae is 56.07 Ma (Jaramillo et al., 2011). One of the distinctive species encountered in Murshe 1 well of the Bornu Basin Nigeria is Zlivisporites blanensis (Ola-Buraimo, 2013). The form has been found in association with the other forms of the Spinizonocolpites Assemblage Zone of Lawal and Moullade (1986) used in dating a section of the Mamu coal facies in the Anambra Basin as Late Maastrichtian. The monosulcate pollen Proxapertites also occurs in the studied section. This species has been described as common in the Paleocene. With these, the sections studied contain long ranging forms that suggest their deposition during Maastrichtian to Paleocene. This is in line with the view of Mebradu (1983). In addition however the sediments collected from the Benin Basin appear younger in age.

Other important forms found in this study are Foveotriletes margaritae and Monoporites annulatus. According to Oloto (1994), Foveotriletes margaritae is a Maastrichtian fossil with biospore zone of A-1 
and is equivalent to Palaeocystodinium australinium dinoflagellate cyst zone of Gbekobo -1 well of Nporo shale. In the same study, Monoporites annulatus was used as Eocene form that is equivalent to Apectodinium cornufruticosum and Amiculosphaeraum bracula dinoflagellate cyst zones of Gbekebo-1 and Nsukka -1, Imo shale and Ameki Formation.

\subsection{Absence of Nannofossils}

In this work, only sediments collected from the southwestern flank of Anambra and few from Bida basins contain palynomorphs that are good enough for geological deduction. All the samples analyzed are barren of nannofossils. Several reasons could be responsible for this. The most important ones are: harsh environmental condition specifically dry climate associated with the drop in sea level causing high salinity and fluvial processes related to the regressive phase; deep and unfavourable bottom water conditions. The issue of carbonate compensation depth (CCD) may not be what has affected nannofossils in the study area. Possibly, it must be a result of weathering that is characteristic of the study area.

\subsection{Evidence of Environmental Destabilization at the K-Pg Boundary}

Bercovici et al. (2012) demonstrated that long-ranging taxa with none or low biostratigraphical value can reveal paleoenvironmental variations across boundary interval. The occurrence of a fern-spore spike event has been shown to associate with the K-Pg boundary at multiple localities in North America (Orth et al., 1981; Tschudy et al., 1984; Fleming \& Nichols, 1990; Sweet et al., 1999; Nichols \& Johnson, 2002; Nichols, 2007; Rook et al., 2010; Bercovici et al., 2012) and in terrestrial and coastal sequences in New Zealand (Vajda et al., 2001, 2004; Vajda \& Raine, 2003; Vajda \& McLoughlin, 2004). Similarly, in the Western Interior, it is marked by a high occurrence $(75 \%$ or more) of Cyathidites and Laevigatosporites within a narrow stratigraphic interval (Tschudy et al., 1984; Fleming \& Nichols, 1988; Nichols \& Fleming, 1990; Bercovici et al., 2012) which can be as thin as $1 \mathrm{~cm}$ (Sweet \& Braman, 1992). In the Northern Southern America province (ASA) the effect of this impact has not been clearly defined (Vajda and Bercovici, 2014).

In this study a spike in the occurrence of Cyathidites and Laevigatosporites is observed in the shale collected at depth $140 \mathrm{ft}$ within Okeluse town (Fig. 3). This sample also contains Proteacidites, which Song et al. (1995) reported its disappearance though among others at the K-Pg boundary within the Taizhou Formation of the Jiangsu Province. Similarly among the three spot samples in the Ahoko section, sample L4 also suggests a spike. In earlier study of the Nigerian coal deposits of the Southeastern Nigeria, Van hoeken-Klinkengerg (1964) observed an increase in the occurrence of Longapertite marginatus along the studied section, which was used to indicate a transition from Cretaceous to Tertiary. Although Longapertite ssp has not been globally used to define K-Pg boundary, in the Ahoko section sample L4 has 3 species suggesting a relatively high occurrence of the form.

Clearly, the number of samples studied makes it difficult to define any systematic increase or decrease in the occurrences of these two forms. Notwithstanding, these coincidences suggest further study of the section to really establish this boundary in Nigeria. Based on the few samples recovered, the sediments of sample L4 and depth 140ft suggest a more conducive marine condition (transgression) and likely marked the K-Pg boundary in the central portion of Nigeria.

\section{Conclusions}

The first down hole shales occurrence of the area around the intersections of three contiguous bains in Nigeria contain long-ranging forms like Echitriporites trianguliformis, Gleicheniidites sp, Zlivisporites blaneensis, Leoisphaeridae sp and Foveotriletes margaritae suggesting Maastrichtian to Paleocene. Notwithstanding, in spite of the few forms recovered, a presumed spike in the occurrence of Cyathidites $s p$ and Laevigatosporites sp in Okeluse, samples at a depth of $140 \mathrm{ft}$ and the lower part of Ahoko section suggest K-Pg boundary. An Iridium anomaly study is suggested for the sections to pin down the relict of this global event in Nigeria. 
Acknowledgements. The authors are grateful to Mosunmolu Nig. Laboratory where the analysis was carried out.

\section{References}

1. Akande, S.O., Erdtmann, B.D., 1998. Metamorphism (thermal maturation) in Cretaceous sediments of the southern Benue Trough and Anambra Basin, Nigeria. American Association of Petroleum Geologists Bulletin. 82,1191-1206

2. Atta-Peters, D., Salami, M.B., 2004. Late Cretaceous to Early Tertiary pollen grains from offshore Tano Basin, southwestern Ghana. Revista Espanola de Micropaleontologia. 36, 451-465

3. Bercovici, D., 2003. The generation of plate tectonics from mantle convection. Earth and Planetary Science Letters. 205, 107-121.

4. Bercovici, D., Ricard, Y., Richards, M.A., 2000. The relation between mantle dynamics and plate tectonics: a primer. In: Richards, M., Gordon, R., van der Hilst, R. (Eds.), the history and dynamics of global plate motions, geophysical monograph, American Geophysical Union, 121, 1-46.

5. Bercovici, A., Vajda V., Pearson, D. A., Villanueva-Amadoz, U., Kline D., 2012. Palynostratigraphy of John's Nose, a new Cretaceous- Paleogene boundary in southwestern North Dakota, USA. Palynology, 36, 36-47.

6. Brownfield, M.E. and Charpentier, R.R. (2006) Geology and Total Petroleum Systems of the West-Central Coastal Province (7203), West Africa. U.S. Geological Survey Bulletin, 2207-C, pp. 52

7. Fleming, R. F., Nichols D J. 1988. The "Tschudy effect": fernspore abundance anomaly at the CretaceousTertiary boundary. Palynology. 12, 238

8. Germeraad, J.H., Hopping, C. A., Muller, J. 1968. Palynology of tertiary sediments from tropical areas. Review Paleobotany and Palynology. 6, 189-348.

9. King, L.C., 1950. Outline and distribution of Gondwanaland. Geological Magazine 87, 353-359.

10. Kogbe, C.A., Ajakaiye, D.E., Matheis, G., 1981.Confirmation of rift structure along the middle - Niger Valley. Nigeria. Journal of African Earth Sciences 1, 127-131.

11. Ladipo, K.O., 1988. Paleogeography, sedimentation and tectonics of the upper Cretaceous Anambra Basin, Southeastern Nigeria. Journal of African Earth Sciences. 7,815-821

12. Jaramillo, C. A., Milton, R., and Vladimir, T., 2011. A palynological zonation for the Cenozoic of the Llanos and Llanos Foothills of Colombia, Palynology, 35, 46- 84

13. Jardine, S., Magloire, L., 1965. Palynologie et stratigraphie du Cretace des Bassins du Senegal et de Cote d'Ivoire. Mem. Bur. Rech. Geology Min. 32, 187-245.

14. Lawal, O., Moullade, M., 1986. Palynological biostratigraphy of the Cretaceous sediments in the Upper Benue Basin, N.E. Nigeria. Rev. Micropaleontol., 29, 61-83.

15. Mebradu, S., 1982. The age of the Ugbogui/Ofumwegbe shales: preliminary report. Review of Palaeobotany and Palynology. 38, 337-344

16. Nichols, D.J.,Fleming, R.F., 1990. Plant microfossil record of the terminal Cretaceous event in the western United States and Canada. In: Shapton, V.L., Ward, P.B. (Eds.), Global catastrophes in earth history: an interdisciplinary conference on impacts, volcanism, and mass mortality. Geological Society of America Special Paper. 247, 445-455.

17. Obaje N.G., 2009. Geology and Mineral Resources of Nigeria, Lecture Notes in Earth Sciences. Springer-Verlag Berlin Heidelberg, pp 69-72

18. Ojo, S.B., Ajakaiye, D.E., 1976. Preliminary interpretation of gravity measurements in the Middle Niger Basin area, Nigeria. In C.A. Kogbe (ed.) Geology of Nigeria. pp. 295 - 307.

19. Ogala, J.E., Ola-Buraimo A.O., Akaegbobi I.M., 2009. Palynological and palaeoenvironmental study of the Middle-Upper Maastrichtian Mamu Coal Facies in Anambra Basin, Nigeria: In World Applied Sciences Journal 7 , $1566-1575$.

20. Phipps, D., Playford, G., 1984. Laboratory techniques for extraction of palynomorphs from sediments. Papers, Department of Geology, University of Queensland, 11, 1-23.

21. Slimani, H., Louwye, S., Toufiq, A., 2010. Dinoflagellate cysts from the Cretaceous-Paleogene boundary at Ouled Haddou, southeastern Rif, Morocco: Biostratigraphy, Paleoenvironments and Paleobiogeography 34, 90-124 22. Sowunmi M, A., 1981. Late Quaternary environmental changes in Nigeria. Pollen et spores. 23,125-148. 
23. Sweet A. R., Braman D. R., 1992. The K-T boundary and the contiguous strata in western Canada: Interactions between paleoenvironments and palynological assemblages, Cretaceous Research, 13, 31-79

24. Tschudy R. H., Pillmore C. L., Orth C. J., Gilmore J. S., Knight J. D., 1984. Disruption of the terrestrial plant ecosystem at the Cretaceous-Tertiary boundary, Western Interior. Science, 225, 1030-1032

25. Vajda V., Bercovici A., 2012. Pollen and spore stratigraphy of the Cretaceous-Paleogene mass-extinction interval in the Southern Hemisphere. Journal of Stratigraphy, 36(2), 153-164

26. Van der Hammen, T., 1956. A palynological systematic nomenclature. Boletin Geologico, 5, 63-101

27. Van hoeken-Klinkengerg P.M.J., 1964. A palynological investiagation of some Upper Cretaceous sediments in Nigeria. Pollen et Spore, 6, 209-231. 